\title{
"There the Facts Are": Andrew Lang, Facts and Fantasy
}

\section{Leigh Wilson}

In an article on Andrew Lang from 1901, G.K. Chesterton wrote in glowing terms of the breadth and scope of Lang's works, of his interest in matters from golf to Homer, from cricket to mythology. It was the nature of Lang's interests, though, that drew Chesterton's warmest praise. Lang, he says, collects "blue china because it is blue" and catches "fish because they are fishy" (481). Chesterton ended his article on Lang with the assertion that it was Lang's peculiar focus on the specifics of each interest that created in his work the sense that "more real facts are neglected in this practical world than we shall ever know" (481). What he called Lang's "overwhelming confluence of specialities" (481) led in the end for Chesterton back to the individual fact, and the individual fact whose reality challenged and upset the dominant view of the world. This reading of Lang as obsessed with facts across disparate subjects appears in most assessments of him, both before and after his death, but for most this "confluence of specialities" indicated his weakness rather than his strength. When Lang died in 1912, and for some time after, even the most sympathetic commentators remarked on the disappointment inherent in his now completed oeuvre. Lang's great friend, the novelist Henry Rider Haggard, quotes in his autobiography, The Days of My Life (1926), a charge that his fellow novelist Mrs Eliza Lynn Linton made to him that "Andrew would be the greatest writer in the language if only he had something to write about." While seeing this as "rather sharp," Haggard admits that Lang "like the amorous Frenchman [. . . ] has ever been wont to éparpiller son coeur over a hundred subjects" (1:229). This assessment of Lang, and a consequent sidelining of his work, has been continued by more recent scholarship, despite the fact that Lang's huge body of work covers many of the areas that have been of most interest to recent scholars of the fin de siècle, particularly literary and cultural historians exploring the intersections of science and culture during the period. Lang wrote a number of books of anthropology; he wrote on folklore and fairy stories; he wrote on and translated the classics; he wrote poetry, novels and short stories; he wrote histories, literary criticism and hundreds of columns in journals and magazines on a vast range of subjects. Despite this, Lang has remained a very minor figure, a footnote. Where he is mentioned, it is often to assert his marginal position; in her history of the British tradition in early anthropology, Henrika Kuklick mentions Lang only to call him an "intellectual gadfly" (56).

Certainly the wide range of Lang's interests and topics and his often lighthearted way of dealing with them does seem to impugn that most venerated of Victorian characteristics, seriousness. However, as Chesterton's praise suggests, one repeated concern of Lang does chime with some of the central and indeed serious concerns of late Victorian culture. It is the case that, throughout his work - both his lighter, more journalistic work and the work he saw as his most serious, his anthropology - Lang privileged facts, stressed the importance of facts, and castigated others for lapses in the presentation of facts. His major challenges to the ideas of others are rooted in the supremacy of facts; "there the facts are" he says very often in conclusion (Myth, Ritual and Religion 1: 5). In this, Lang's work seems to fit with a question which underlies many of the debates of the second half of the nineteenth century, as science hardened its boundaries and at the same time sent its methods and 
assumptions out into those areas beyond them. Across the period, at stake in so many debates, in so many developments in scientific understanding and for so many of those who resisted them, is the relation between the substance of the world, that which is experienced through the senses, and what it means. Work in the history and philosophy of science has done much to unravel the complex relations between science and facts, and between science and its supposed 'others' through the course of the nineteenth century, but sharp divergences are visible across this work which suggest that there is still much to be said in this area. In particular, despite attempts to see the interactions between science and its perhaps most extreme 'other' - the literary - as complex and nuanced, these relations are still the site of disagreement. In his study of the legacies of Baconian induction in nineteenth-century science, for example, Jonathan Smith, in Fact and Feeling: Baconian Science and the NineteenthCentury Literary Imagination (1994), sees through the period a fundamental instability and equivocation - between ideas of scientific knowledge and the imagination, between facts and feelings - at the heart of scientific method and debate. While increasingly through the century he argues that a "naïve Baconianism" was challenged and the role of imagination and speculation in science was gradually brought to the fore, such shifts could not then help but threaten science's claims to tell the truth and so send it back to its factual basis. In discussing William Whewell's assertion that facts and theories are inseparable, Smith argues that "[ $t]$ he implication is that ultimately there is no such thing as pure facts, but such an implication would just as clearly threaten the very foundations of science's authority, its access to knowledge that is true and permanent" (21).

Smith's focus is the literary and the evidence he presents reveals the continued imbrication of the scientific and the literary. The relation between the two was an anxious back and forth in which scientists and literary writers borrowed from each other, anxiously qualified that borrowing, then denied it and asserted difference, only to be sent back through the consequences of such denials to claims of mutuality and borrowing. However, in contrast, in tracing the construction of the concept of objectivity in science through the nineteenth century in their Objectivity (2007), Lorraine Daston and Peter Galison, whose focus is the work of scientific imagemakers, argue that towards the end of the century scientists yearned not for imagination but the "blind sight" of objectivity; an objectivity which aspired "to knowledge that bears no trace of the knower - knowledge unmarked by prejudice or skill, fantasy or judgment, wishing or striving" (17). In opposition to a vision of the nineteenth century in which a veneration of Baconian induction gave way to a deductive method that made necessary speculation and interpretation, Daston and Galison assert that:

In notable contrast to earlier views held from the Renaissance through the Enlightenment about the close analogies between artistic and scientific work, the public personas of artist and scientist polarised during this period [. . . The scientific self of the mid-nineteenth century was perceived by contemporaries as diametrically opposed to the artistic self, just as scientific images were routinely contrasted to artistic ones. (36)

The place of facts in nineteenth-century science, and the effect of this on the relations between science and its 'others', remains a live question, then, one still inflected by our own sense of values and disciplinary boundaries. 
However, it is the case that what both the examples above share, despite their difference, is the sense that facts are key, and that they are fundamental to a scientific understanding of the world. While Smith's argument shows the complex back and forth between science and the literary, facts always remain firmly on the side of science. The tenacity of such a relation between science and facts can also be seen in the famous and influential debate in the 1880s between T.H. Huxley and Matthew Arnold on the relative merits of science and the classics as a basis for education. At the core of Huxley's challenge to the privileging of the humanities, and classics in particular, is his distinction between the facts of the natural world and words. Science as a "criticism of life" is for him more powerful than its rivals in the humanities because it "appeals not to authority, nor to what anybody may have thought or said, but to nature" (226). For Huxley science is pre-eminent not through a denial of the role of the observer and of all that is outside the realm of facts, but because, despite the power of the extra-factual, science insists again and again on the return to facts. In this, what is particularly challenged is the role of language:

[Science] admits that all our interpretations of natural fact are more or less imperfect and symbolic, and bids the learner seek for truth not among words but among things. It warns us that the assertion which outstrips evidence is not only a blunder but a crime. (226-7)

In Arnold's reply to Huxley, in his Rede Lecture given at Cambridge in June 1882 and printed in The Nineteenth Century in the same year, this distinction between words and facts is not disputed. Arnold acknowledges the split between words and things as the basis for scientists' assertion of the pre-eminence of their discipline, and concurs with the split: "This reality of natural knowledge it is, which makes the friends of physical science contrast it, as a knowledge of things, with the humanist's knowledge, which is, say they, a knowledge of words" (222). Where Arnold differs from the assessment of the "friends" of science is that he asserts, not that this is not the case, but that it is not enough. Human beings, he says, while they like to gather interesting facts, have a desire to link these facts to "our sense for conduct, to our sense for beauty" (223). Here Arnold asserts the move toward deduction rather than induction that Jonathan Smith argues is the overall tendency of the institutions and practices of science during the century. However, in Arnold, as in the assertions of Huxley, the assumption remains that facts and the literary are quite separate and separable things, however much both are necessary.

In what follows this article will argue that Lang's obsession with facts challenges both the battle lines of his contemporaries and those of more recent readings of the period. Lang's work suggests a quite different way of reading the relation between facts and fantasy during the period. In his work, the relations between facts and fantasy are often strange and contradictory, and the overall effect is to challenge the boundaries between science and its others. They demonstrate in their contradiction and awkwardness an impossibility within science that perhaps has not always been acknowledged. Lang's obsession with facts, his resistance to occupying just one disciplinary category, his intellectual restraint in terms of making up his mind, his dilettantism, can all be seen then, not as the reasons for his failure, as so many have suggested, but as the reasons for his significance.

This article will focus on two works by Lang, The Making of Religion (1898) and his short story "Romance of the First Radical" (1880), to show that while Lang's work ostensibly privileges facts according to the contemporary dictates of science, his 
extreme assertion of their importance and his practice of interdisciplinarity has the effect of challenging the nature and status of the 'facts' of science. In both these works an ostensible cleaving to the methods and practices of science is shot through with a remaking of facts so that they have within them effects beyond the possibilities of empiricism; indeed, so that they contain within them the fantasised world of the literary.

\section{The Making of Religion: A Book in Two Halves}

The publication of The Making of Religion marked a particular culmination of Lang's work in anthropology. It established him as vital to anthropological debate and in particular as crucial in his championing of anthropology as a science. His work in anthropology had begun in the 1860s and his first important contribution was his assertion that anthropology was a science to the extent that its evidence consisted of facts (see: Custom and Myth 1884); he continued to denigrate theory or speculation throughout his career (see: "Science and Superstition" 1901). Lang's challenge to the philological work of Friedrich Max Müller on the origin of myths was precisely that Müller's theories were the result of scholarly fantasy rather than a consideration of the hard facts, that indeed the philologists were concerned with words rather than things. For Lang myths should be read not through words - they are too ephemeral, not sufficiently linked to the facts of the world - but through the material conditions of "early man" and the thinking produced by them:

The truth is, that while languages differ, men (and above all early men) have the same kind of thoughts, desires, fancies, habits, institutions. It is not that in which all races formally differ - their language - but that in which all early races are astonishingly the same - their ideas, fancies, habits, desires - that causes the amazing similarity of their myths. (Modern Mythology xvi)

More than this, not only does a focus on language misunderstand what is crucial about early human culture, but it allows the element of fantasy to creep in. The philological scholar, fixated on names, is led to explain myths only "in accordance with his private taste, easily accommodating the facts of the myth, whatever they may be, to his favourite solution" (xvii).

However, if it is in the field of anthropology that Lang most clearly claimed to work in and to define a science, it was precisely here that, in his treatment of the role of facts in The Making of Religion, he resisted its nascent disciplinary etiquette and boundaries. Unlike the central anthropologists of the period, including E.B. Tylor, whom Lang saw as his model and mentor, Lang did not balk at the increasing occurrence in modern society of those beliefs and practices which anthropology studied in 'primitive' cultures. While Tylor noted the similarities between them in Primitive Culture, Lang wanted to go further. In his introduction to a collection of essays published on the occasion of Tylor's $75^{\text {th }}$ birthday, Lang acknowledged that "Mr. Tylor's affair was to discover great numbers of ethnological parallels to the speciosa miracula of spiritualism, and to leave the matter there for the present" ("Edward Burnett Tylor" 8). Lang, on the other hand, did not leave it there, and in a number of places in the 1890s - in Cock Lane and Common Sense (1894) and in The Making of Religion in particular - he asserted the need for anthropology to acknowledge and take seriously the aims, methods and evidence of psychical research in the area which anthropology had previously dismissed as 'fantasy'. In a letter to 
the psychical researcher Henry Sidgwick he was more forthcoming: "Of course my Psychics are very unpopular, but Tylor brought them in, and left them in, and left them hanging in air, and did little to the civilised side of them. This was hardly scientific in my opinion" (qtd. in DeMoor 94). Here Lang claims science as his authority for including the fantastical material of psychical research in his anthropology. Yet Lang's treatment of these as 'facts' in The Making of Religion and his linking of them to the 'facts' of the early belief in a supreme god changes the nature of facts from those accepted by mainstream science at the time.

The Making of Religion is split into two parts, the first part looking at a number of "savage beliefs" and practices which had recently resurfaced, particularly since the beginnings of modern spiritualism in the 1840s. These chapters cover clairvoyance, crystal gazing, hallucinations, possession and the use of divining rods, and point out the convergence of accounts of such practices across traditional cultures, in the European past and in contemporary Europe. The second half of the book consists of Lang's most sustained challenge to date to the prevalence of the "ghost theory" among anthropological accounts of the origins of religion. This theory was first articulated and named by Herbert Spencer, initially in an article in The Fortnightly Review in 1870 and then in more detail in Volume 1 of his Principles of Sociology (3 volumes, published between 1874 and 1896). Spencer argued that those things which seemed unaccountable and absurd in 'savage' beliefs and practices in fact show that people in early and traditional societies thought logically with the material at their disposal. He suggested that savage beliefs and practices hallucinations, possession, the belief in the animation of the inanimate, and the belief in spirits - all had their origin in traditional people's observation of the dead and of reflections in water, and in their experience of altered states of consciousness. All of these led early people to assume that humans have a "second personality," a double, distinct from the physical body, which survives death and can travel across distance and time ("The Origins of Animal-Worship" 536-7). This ghost theory, then, provides the basis of all beliefs in non-material beings and occurrences for Spencer, and for him constitutes the origin of religious belief per se. Belief in this double and its consequences evolved, he argues, eventually into what anthropology defined as religious belief.

At around the same time as Spencer fully elaborated his theory in the Principles of Sociology, E.B. Tylor was arguing too in his Primitive Culture (1871) for a version of the ghost theory. His concept of "Animism" describes "the deep-lying doctrine of Spiritual Beings, which embodies the very essence of the Spiritualistic as opposed to Materialistic philosophy" (1:425). Tylor asserted explicitly that animism underlay all religious belief; it is "the groundwork of the Philosophy of Religion, from that of savages to that of civilised men" (1: 426). For Tylor too the beginnings of animism were in early people's misunderstanding of dreams, abnormal states of consciousness and dead bodies (1: 428). In both Spencer and Tylor, these accounts of the origins of religious belief was set, sometimes explicitly and sometimes more implicitly, within an evolutionary model which saw "progress" from magical beliefs, through religious belief, and finally arriving at science's true view of the world (Stenski 117). For Spencer and Tylor, and later James Frazer, magical and religious beliefs were rooted in facts but in their misreading, and this only changed when science, the result of progress in human understanding, could eventually read facts correctly.

Lang's challenge to the ghost theory, which he maintained throughout the rest of his life, writing his final complete statement of it in 1908 in "Theories of the 
Origins of Religion," was that it ignored a substantial body of facts which suggested that, rather than the belief in "ghosts" leading eventually to religious belief, a belief in a supreme god was among the earliest of beliefs. This challenge was to one of the cornerstones of anthropology as it constructed itself as a 'scientific' discipline in the late nineteenth century. By the 1890s the ghost theory, and variants on it, had become the orthodoxy among anthropologists, and was even taken as such by lay people, as acknowledged in Grant Allen's popularising work, where he asserts as "proved almost beyond the possibility of doubt Mr. Herbert Spencer's luminous theory of the origin of polytheism from ghost worship and ancestor worship" (489). Lang's challenge powerfully undermined the status of the theory and while he was on the whole disappointed by the reaction from his fellow British anthropologists, particularly Tylor (see: "Theories of the Origins of Religion" $120 \mathrm{ff}$.), it was later acknowledged as being responsible for "knocking another nail into the coffin of Herbert Spencer's theory of the origin of religion" (Jennings Rose 25).

Lang's anthropology in his challenge to the ghost theory pits facts against theory in a way that suggests his idea of science is one of extreme empiricism. However, this straightforward alignment of Lang and hard facts is made problematic by the first half of The Making of Religion. Lang asserted that the two halves of his book - one concerning the 'facts' of psychical phenomenon and the other the 'facts' of early belief in a supreme god - worked together and strengthened each other. However, that the relation between the two is problematic can be seen in the first reactions to The Making of Religion. Of these, one which particularly disappointed Lang was the inability of readers to see the links between its two parts, to understand, in other words, his attempts to link the 'facts' of psychical research and the 'facts' of anthropology. In his preface to the second edition of the book in 1900, Lang acknowledges that:

Thanks to this daring novelty, the book has been virtually taken as two books; anthropologists have criticised the second part, and one or two Psychical Researchers have criticised the first part; each school leaving one part severely alone. Such are the natural results of a too restricted specialism. ("Preface" viii)

Lang attempts to account for this failure to understand what he is doing at the beginning of his preface to the second edition:

By the nature of things this book falls under two divisions. The first eight chapters criticise the current anthropological theory of the origins of the belief in spirits. Chapters ix.-xvii., again, criticise the current anthropological theory as to how, the notion of spirit once attained, man arrived at the idea of a Supreme Being. These two branches of the topic are treated in most modern works concerned with the Origins of Religion, such as Mr. Tyler's "Primitive Culture," Mr. Herbert Spencer's "Principles of Sociology," Mr. Jevons's "Introduction to the History of Religion," the late Mr. Grant Allen's "Evolution of the Idea of God," and many others. Yet I have been censured for combining, in this work, the two branches of my subject; and the second part has been regarded as but faintly connected with the first. (vii) 
While it is true that "most modern works" cover both areas, they do not, like Lang, consider the first area as consisting of facts but rather as evidence of the obscuring work of fantasy in both early people and contemporary spiritualists. Moreover, if we take Lang at his word and try to construct a relation between the material presented in the opening chapters of the book and the detail of his challenge to the ghost theory, Lang's position becomes more strange and difficult to rationalise according to the demarcation which locates facts firmly on the side of empirical science and as problematically related to fantasy and the fictional.

Lang's central argument in the first part of The Making of Religion is that beliefs about psychical phenomenon are based on verifiable facts, even if these facts are erroneously accounted for by traditional people themselves. In other words, he remains within mainstream anthropology's claim to explain facts misread by traditional peoples, but what he takes as facts are not the dead bodies and states of abnormal consciousness of Spencer's ghost theory or Tylor's animism but the psychical phenomenon of clairvoyance, divining rods, crystal gazing, and so on. In Lang, the fantasy of Spencer and Tylor becomes fact. However, this is quite different from what he says about the origins of religion. Lang is not arguing that early peoples first had an idea of a creator and 'all father' because they based their assumptions on empirically experienced facts. Indeed, it may be that the charge against Lang made at the time - that his theory implied his assertion of the truth of divine revelation - was due to reading the two parts as parallel in their deductions. Lang insisted on the error of these readings, telling fellow anthropologist R.R. Marett in a letter in 1900 that he was anxious that his theories would seem "in no way mystical" (Marett 11). Indeed, in his challenge to the ghost theory Lang is not arguing that the existence of such beliefs suggest that the existence of God is a fact. Lang does not really ever attempt to give a reason for these early beliefs in a supreme god - the "high gods of low races" as he calls them in chapter 10 of The Making of Religion - he rather argues on the basis that such beliefs do exist, so the ghost theory cannot be correct. He acknowledges that "existing evidence will hardly support any theory of religion" (321), but nevertheless that evidence does exist for beliefs in a supreme god before any idea of propitiation, ancestor worship or belief in ghosts. Lang's insistence then that traditional beliefs about psychical phenomena are based on facts, and should therefore be investigated, is not structurally the same as his challenges to the ghost theory. In the former Lang is asserting that beliefs are based on the facts of experience; in the latter only that beliefs themselves exist as facts. However, that Lang wants these to work together is suggestive of his sense of the nature of facts. While Lang insists on separating facts from theories, what he will not separate is facts from fantasy.

Indeed, it is this assertion of facts outside any theory that, while seeming to align Lang with the most extreme empiricism, actually returns to facts something quite different. It is the case that much of Lang's work was prompted by a dislike of totalising theories, and he resisted the assumption that facts lead to totalising theories which finish or complete knowledge, and are significant only in as much as they lead to them and prove them (see: "Science and Superstition" 1901). For Lang facts are not this; rather they are in part a marker of strangeness and unaccountability. Facts for Lang remain isolated from a coherent and cohesive meaning that would explain them. The 'facts' of psychical research and the 'facts' of early beliefs in a supreme god may not be the same kind of facts, but what they share is a salience from the world made orderly by explanation. They are unlikely, incongruous, marvellous. They are, in other words, much more like fantasy. In his challenge to Spencer, in effect Lang 
contests not just the specific claims of the ghost theory, but also the desire for total theory per se, and its implicit insistence that a survey of the facts via a scientific method could lead to a full account of and explanation for something.

What does link the two parts of The Making of Religion, then, is an insistence that facts need to be acknowledged and taken seriously, even when their existence is problematic for the theories of scientists. Lang asserts that the 'facts' of psychical experiences and the 'facts' of early beliefs in a supreme god need to be acknowledged even though they both challenge the central orthodoxies of disciplines assumed to be 'scientific'. In other words, these facts make necessary a change in what other facts mean. In this, Lang would seem to take the position of a hardline empiricist, and yet, as I have suggested, the nature of his book led to it being misread as a claim for divine revelation and for an innate sense of the divine in human beings. While in both parts of the book Lang insists that certain facts, however uncomfortable, must be acknowledged - whether of the prevalence of similar accounts of crystal gazing widely across time and space or of beliefs in an 'all father' - this insistence on a recognition of facts does not fit together into one clear position for Lang. Not all 'facts' are the same and Lang's linking together of these two groups of 'facts' troubles the division between facts and fantasy, between substance and interpretation. Facts, then, no longer belong to science, even if, as Lang insists, our attitude to them must be 'scientific'.

\section{"Romance of the First Radical": Facts and Romance}

Lang's "scientific" work, then, for all it tries to assert the status of science and its privileged relation to truth, returns again and again to the imbrication of fact and fantasy. This return can be seen too in his fictional writing. In "Romance of the First Radical," (first published in Fraser's Magazine in 1880) while again Lang ostensibly tries to keep them apart, in the end it is fictional writing that gives us the facts. This position seems to mark Lang as in opposition to the broad trend of the century. In his work on the popularizing works of geology in the nineteenth century, Ralph O'Connor has argued that the use of literary techniques in order to reconstruct the 'fantasy' worlds of prehistory was vital in communicating the discipline's recent discoveries. What O'Connor calls "imaginative restorations" (10) were not decorative tropes, but necessary in communicating the truth of the world. As he acknowledges, in the early part of the period, "the written word was widely felt to be the most reliable vehicle for calling up [. . .] pictures in the mind's eye" (4). However, in the later part of the period, John Tyndall's claim in his "Belfast Address" in 1874 that science involved imagination was qualified specifically around the ability to call up mental images, mental images produced not by words but by a knowledge of nature. Truths about nature "fall into place as a physical image" (12) for Tyndall without the mediation of literary writing. However, Lang's work does not nostalgically rest on earlier notions of the power of fictional writing. Rather, in its awkwardness and strangeness, it implicitly claims that power through its acknowledgement of science's claim to the fact.

In her article on Lang's short story, "Romance of the First Radical," Julie Sparks has argued that the tone and aim of the story is primarily satirical, and that in the story "the techniques of satirical fiction work in tandem with [. . .] scientific method" (132), indeed that the story is "both a work of fiction and a replica of 'straight' scientific writing" (131). In her reading of the story, she sees Lang as using the assumptions and methods of mainstream science at the time in a straightforward way: 
Just as Darwin examined the tiny points on modern human's [sic] ears and deduced that our proto-human ancestors' ears were pointed, Lang looks at contemporary customs that seem peculiar to a rationalist and concludes that they must be vestiges of a former, more primitive culture. (137)

Sparks's reading does acknowledge the difficulty of the relation between fact and fantasy, however. From arguing that Lang constructs his fiction by using the methods and assumptions of science, and anthropological science in particular, she ends her reading with the acknowledgement that "scientists trying to reconstruct prehistory are - at least to some degree - story-tellers" (140). But science's complex and strained attempts to marry induction and deduction, observation and reconstruction, fact and imagination, through the century, brought to the surface in particular in those disciplines whose subject was the past, are rather smoothed out here. Whether Lang the short story writer is a scientist or whether the scientist is a "story-teller," however, what Sparks's reading implies is that science sits on one side, fiction on the other, and that Lang's story coheres the relation between the two. However it can be argued that "Romance of the First Radical" does not solve the dilemma of the relation between fact and fantasy, but rather enacts it through its reframing of the nature of facts. Lang uses both induction and deduction in the story, observation and reconstruction, but crucially they only work together because the story is fiction, and the methods are split between narrator and protagonist. That fiction provides the possibility for this coming together both reveals the troubled and difficult nature of the claims of science during the period, and privileges fiction as a site of the fullest possible truth.

That Lang calls his short story a "Romance" is crucial here. Lang's use of the term through the 1880s itself suggests the difficult nature of the relation between fact and fantasy, and the crucial place of fiction in it. In various places in his writing, Lang attempted to demarcate the scientific from the romantic, the nature of the fact from fantasy in the form of fiction. At points in this work this demarcation seems clear and stable. In his article, "Émile Zola," from 1882, Lang bases his criticism of Zola's theory, and his practice of it in his novels, on the insistence that science and literature are fundamentally different categories: "The word 'science' is always in [Zola's] mouth, and it does not seem to occur to him that art and literature are one thing, and science quite other" (443). It is not, Lang says, that the contents of each are in themselves problematic, but what is problematic is the contents of one category appearing in another: "the details of the dissecting-room, innocent in themselves, need not be discussed in the drawing-room" (443). Lang seems here not only to refuse a mixing of categories, but to cede to science precisely the possession of the facts of nature. Zola's failures as a novelist, for Lang, are precisely his attempts to be "scientific": "He is as cold as a vivisectionist at a lecture" (452). Here, then, it is not that the content of Zola's novels is not true (or not necessarily); rather that the facts of Zola's novels are inappropriate to their setting.

However, elsewhere the nature of this boundary is less clear. Writing on The Wrecker, by Robert Louis Stevenson, in The Illustrated London News, Lang asks to what extent a novelist's method should be visible in their work: "should a novelist break up his own toy, and take us behind his own scenes?" Lang's conclusion is equivocal, torn between the claims of fact and those of fiction:

One's pleasure in fiction is always hurt when one recognises blocks of raw fact in the material [. . .] These remarks are, after all, perhaps too 
individual; many readers may actually enjoy seeing the toy taken to pieces, may be pleased to watch the disintegration of the puppets. It is an odd taste, but it may be a taste which is prevalent. We are too curious; we have too much of the scientific spirit even in our pleasures. ("Behind the Novelist's Scenes" 83)

Some years later, in defending himself against a charge by George Moore than he unfairly keeps Zola out of the category of "Romance," Lang attempts again to delineate a "scientific" use of the word ("Romance and the Reverse" 4) and in doing so seems to rub out delineation per se. He says that romance is not always impossible, and that the impossible is not always romance, that novels can contain romance, and that "romances" can be unromantic. In introducing the crisscrossing of definitions here, Lang almost concedes that what "romance is, perhaps nobody will ever be able to define" (3). In the end, though, Lang suggests that romance is best defined as "that element which gives a sudden sense of the strangeness and the beauty of life; that power which has the gift of dreams" (4). It is a matter of vision rather than subject matter: "it is equally obvious that profusion of adventure no more makes a work 'romantic' - if the writer lacks vision - than the profusion of squalid incident and detail makes a book 'realistic' if the writer lacks the sense and grasp of realities" (4). Here, it is not so much the facts included in a novel that makes it realist or romantic, then, but the way that those facts are seen. However, the proper vision makes facts, not assimilatible into a total vision, orderly and controlled, but strange.

Sparks's claim that fact and fiction are "in tandem" in "Romance of the First Radical" seems unlikely, given the nature of Lang's attempts to think through romance and its relation to facts in his journalism, and indeed the story itself is much stranger than Sparks's reading allows. At the outset, the story claims to be the scientific reconstruction, on the part of the narrator, of that which left no trace in history, but which is 'true' to the extent that it is reconstructed using the methods of comparative anthropology:

The Devil, according to Dr. Johnson and other authorities, was the first Whig. History tells us less about the first Radical - the first man who rebelled against the despotism of unintelligible customs, who asserted the rights of the individual against the claims of the tribal conscience, and who was eager to see society organised, off-hand, on what he thought a rational method. In the absence of history, we must fall back on that branch of hypothetics which is known as prehistoric science. We must reconstruct the Romance of the First Radical from the hints supplied by geology, and by the study of Radicals at large, and of contemporary savages among whom no Radical reformer has yet appeared. In the following little apologue no trait of manners is invented. (179-80)

In the story, Lang clearly uses anthropological evidence from contemporary studies of Australian aboriginal culture, from totemistic practices and from the mythologies of various peoples in his work of reconstruction. Like the early geological writers, his story draws attention to the fact that such scientific work is the construction of precisely a story, one of O'Connor's "imaginative restorations," science's need for which throughout the century made so problematic its assertion of its basis in fact. This is what the story does; but what it reconstructs is the life of the "First Radical" whose break with tradition consists of the discovery of the methods of induction. The 
story has as its protagonist a young man called Why-Why, living among his tribe "shortly after the close of the last glacial epoch in Europe" (180). Why-Why questions the superstitions and magical practices of his tribe using the inductive method. He observes the world, experiments with that which he observes and uses his experience in order to disprove the 'truths' of traditional belief. He eats oysters before he has been initiated into manhood, the consequence of which, according to the mythology of his tribe, and based on the ideas of sympathetic magic, should be that "the earth would open and swallow the culprit":

Not daunted by this prevalent belief, Why-Why one day devoured no less than four dozen oysters, opening the shells with a flint spear-head, which he had secreted in his waist-band. The earth did not open and swallow him as he had swallowed the oysters, and from that moment he became suspicious of all the ideas and customs imposed by the old men and wizards. (187-8)

Because of such challenges to traditional belief, Why-Why is eventually estranged from his tribe and lives for two years in a kind of paradise with his lover, a young woman from another tribe called Verva. However, this idyll - which is described as being "like a dream" (205) - is destroyed when a party from his own tribe, led by the chief medicine man, finds them and kills them both. Their relations have offended the totemistic taboos of their tribe as Why-Why and Verva are of the same totem. After the death of his protagonist, who has challenged superstitious religious belief through his inductive method, Lang's deductive narrator does not link Why-Why with science, however. Here, he differs from the anthropological, despite his use of the comparative method to frame his story and give it authority. In the ghost theory of Spencer, and in Tylor's animism, magical beliefs are rational views of the world, given certain conditions and premises, which are eventually superseded by the rational methods of science itself. This evolutionary line was, of course, made even more clear and central by Frazer in The Golden Bough, for whom magic is more like science than either are like religion, but which nevertheless is eventually superseded by science because it, unlike science, is wrong about the relations between cause and effect (59). However, at the end of Lang's story, the evolutionary leap made by WhyWhy through his radical questioning and his refusal to accept the authority of tradition is linked by the narrator not with science but with poetry:

Many thousands of years later the cave was opened when the railway to Genoa was constructed, and the bones of Why-Why, with the crown, and the fragment of iron, were found where they had been laid by his repentant kinsmen. He had bravely asserted the rights of the individual conscience against the dictates of Society; he had lived, and loved, and died, not in vain. Last April I plucked a rose beside his cave, and laid it with another that had blossomed at the door of the last house which covered the homeless head of SHELLEY. (209)

Here Lang's ostensible championing of induction against the conservative superstition of early human culture is made less straightforward by its articulation via the reconstructions of the deductive method, by its "romance," and by its explicit linking of his hero with Shelley, who may have been, as Sparks argues, "the most famous persecuted freethinker of the period" (133), but who was also a Romantic 
poet. In his essay "Realism and Romance" (1887), Lang links the desire to read such romances with Tylor's idea of survivals - those elements of "primitive culture" which persist, anachronistically, into the present - and the literary per se: "If we will only be tolerant, we shall permit the great public also to delight in our few modern romances of adventure. They may be 'savage survivals' but so is the whole of the poetic way of regarding Nature" (690). The reader of "Romance of the First Radical," then, is acting on that which remains in them of the "savage," that within them that misreads facts, that confuses what is in the world and what is in their mind. In doing so, the reader uses their residue of "savagery" in order to read, via a narrative of "creative restoration," of a character who sloughs off his own "savagery" through the inductive methods of science and who is in his turn linked with the "poetic way of regarding Nature." In this story fact and fantasy are bound so tightly together that they cannot be separated.

This remaking of the fact in Lang's work has wide implications. In the work of Bruno Latour, the status of the fact is seen as the most crucial point for the whole conceptual edifice, not just of science but of modernity per se. In We Have Never Been Modern, Latour challenges the claim of the sciences, the hard and the social, that they make meaning from a position of objectivity and reveal those places where unilluminated subjectivity reigns (in the non-modern, the traditional, the working class and so on). Latour makes it clear that modernity is per se the act of division and the institution of boundaries - "we are modern. Our fabric is no longer seamless" (7) - and that the primary boundary of modernity is that which "cleanly separated material causality from human fantasy," in contrast to "the olden days, which illegitimately blended together social needs and natural reality, meanings and mechanisms, signs and things" (35). Latour's work shows, however, that this construction of modernity is contrary and impossible - the relation between nature and human thought is constantly breaking down within these central vehicles of Enlightenment thought. In On the Modern Cult of the Factish Gods, Latour argues that the primary division that modernity makes between nature and human imagination and fabrication - between true facts and constructed fetishes in Latour's terminology - is itself a human fabrication. Against this, he urges that both facts and fetishes are fabricated, and that both can be true: "Within the depths of their roots, both conceal the intense work of construction that allows for both the truth of facts and the truth of minds" (21). Facts then are fundamental to the discourse of science and to the claim that we are "modern," but, as Latour argues in We Have Never Been Modern, the very claims made for facts by science implicate science in that which it would disavow, human fantasy. Summing up the effects of Robert Boyle's work in the seventeenth century on the construction of science as a discourse, Latour glosses both the claims and their implications:

In themselves, facts are mute; natural forces are brute mechanisms. Yet the scientists declare that they themselves are not speaking; rather, facts speak for themselves. These mute entities are thus capable of speaking, writing, signifying within the artificial chamber of the laboratory [. . .]With Boyle and his successors, we begin to conceive of what a natural force is, an object that is mute but endowed or entrusted with meaning. (28-9)

Science then relies on a notion of the fact within which fantasy resides, not as a contradiction but as an essential part of its construction. Lang's work, through its 
contradictions and its at times troubled interdisciplinarity, makes visible the extent to which the imbrication of fact and fantasy lies at the heart of late-Victorian science and its access to truth. 


\section{Works Cited}

Allen, Grant. "Ghost Worship and Tree Worship." The Popular Science Monthly, Feb.1893: 489-504.

Arnold, Matthew. "Literature and Science." The Nineteenth Century, Aug. 1882: 21630.

Chesterton, G.K. "Mr. Andrew Lang: An Appreciation.” Literature 23 Nov. 1901: 481.

Daston, Lorraine and Peter Galison. Objectivity, New York: Zone Books, 2007.

DeMoor, Marysa. "Andrew Lang (1844-1912): Late Victorian Humanist and Journalistic Critic with A Descriptive Checklist of the Lang Letters." Vol. 1. PhD Diss. University of Ghent, 1982-3.

Frazer, James. The Golden Bough. 1922. London: Penguin, 1996.

Haggard, Henry Rider. The Days of My Life: An Autobiography, 2 vols. London: Longmans, Green and Co., 1926.

Huxley, T.H. "Science and Culture." (1880). Essays English and American, Ed. Charles W. Eliot, New York: P.F. Collier and Son, 1910.

Kuklick, Henrika. "The British Tradition." A New History of Anthropology. Ed. Henrika Kuklick. Oxford: Blackwell, 2008.

Lang, Andrew. "Behind the Novelist's Scenes." Illustrated London News, 16 July 1892: 83.

---. Cock Lane and Common Sense. London: Longmans, Green and Co., 1894.

---. Custom and Myth. London: Longmans, Green and Co., 1884.

---. "Edward Burnett Tylor." Anthropological Essays Presented to Edward Burnett Tylor, In Honour of his $75^{\text {th }}$ Birthday, October 2 1907. Ed. W.H.R. Rivers, R.R. Marett and Northcote W.Thomas. Oxford: Clarendon, 1907.

---. "Émile Zola." The Fortnightly Review, 31:184 (April 1882): 439-52.

---. The Making of Religion. London: Longmans, Green and Co., 1898.

---. Modern Mythology. London: Longmans, Green and Co., 1897.

---. Myth, Ritual and Religion. 2nd ed. Vol 1. London: Longmans, Green and Co., 1899.

---. "Preface." Cock Lane and Common Sense. 2nd ed. London: Longmans, Green and Co., 1895.

---. "Preface." The Making of Religion. 2nd ed. London: Longmans, Green and Co., 1900.

---. "Realism and Romance." The Contemporary Review. 52 (November 1887): 683-93.

---. "Romance and the Reverse." St. James's Gazette 7 Nov. 1888: 3-4.

---. "Romance of the First Radical." In the Wrong Paradise and Other Stories. London: Kegan Paul, Trench \& Co., 1886.

---. "Science and Superstition." Magic and Religion. London: Longmans, Green and Co., 1901.

---. "Theories of the Origin of Religion." The Origins of Religion and Other Essays. London: Watts \& Co., 1908.

Latour, Bruno. We Have Never Been Modern. Trans. Catherine Porter. Cambridge, MA: Harvard UP, 1993.

Latour, Bruno. On the Modern Cult of the Factish Gods. Trans. Catherine Porter and Heather MacLean. Durham and London: Duke UP, 2010. 
Marett, R.R. "The Raw Material of Religion." (1929). Concerning Andrew Lang: Being the Andrew Lang Lectures delivered before the University of St Andrews 1927-1937. Oxford: Clarendon Press, 1949.

O'Connor, Ralph. The Earth on Show: Fossils and the Poetics of Popular Science, 1802-1856. Chicago and London: U of Chicago P, 2007.

Rose, Herbert Jennings. Andrew Lang: His Place in Anthropology. Edinburgh: Thomas Nelson, 1951.

Smith, Jonathan. Fact and Feeling: Baconian Science and the Nineteenth-Century Literary Imagination, Madison: U of Wisconsin P, 1994.

Spencer, Herbert. "The Origins of Animal-Worship.” Fortnightly Review. May 1870: 535-50.

Spencer, Herbert. The Principles of Sociology. 3rd ed. Vol 1. New York: D. Appleton and Company, 1901.

Tylor, E.B. Primitive Culture. 2 vols. 3rd US ed. from 2nd British ed., New York; Henry Holt and Company, 1889.

Tyndall, John. "Belfast Address." Inaugural Address, Delivered at the Forty-Fourth Annual Meeting. The British Association for the Advancement of Science, Belfast, August 1874. Melbourne: George Robertson, 1874.

Sparks, Julie. "At the Intersection of Victorian Science and Fiction: Andrew Lang's "Romance of the First Radical."' English Literature in Transition 1880-1920 42.2 (1999):125-42.

Stenski, Ivan. "The Spiritual Dimension.” A New History ofAnthropology. Ed. Henrika Kuklick. Oxford: Blackwell, 2008. 